\title{
Anders Lindseth
}

Nord University, Centre for Practical Knowledge, NO-8049 Bodø

anders.lindseth@nord.no

\section{What Is at Stake in the Narrative of the Guests of Philosophical Practice?}

\begin{abstract}
In the dialogues of Philosophical Practice, the philosopher has to continuously ask himself or herself what is at stake in the narratives of the guests. What are their stories really about? Special, responsive attention is required in such dialogues. This paper is an attempt to clarify the difference between a philosophical dialogue and other dialogues, such as ordinary everyday dialogues and dialogues with experts, especially with professional helpers. Philosophical Practice is understood as being about interpreting a guest's message as self-communication, while outside the practice room, it is usually experienced and seen as a form of address or information. It is a challenge of ethical nature that the Philosophical Practitioner can open up a space of attention in the dialogue where the self-communication of the guest may be perceived anew and thus making possible a new orientation in life. Philosophical Practice is aiming at freeing such self-communication from discourse and locating it in nature and freedom.
\end{abstract}

\section{Keywords}

dialogue, discourse, ethics, hermeneutics, information, narrative, phenomenology, realism, self-communication, truth

\section{A Story Comes First ${ }^{1}$}

In the mid-1980s, at the Inter-University Centre in Dubrovnik, I met a philosopher from Hamburg who told me that in Bergisch Gladbach in Germany a philosopher, Gerd B. Achenbach, had opened a Philosophical Practice where he talked to people who needed conversations, without considering these conversations as therapy. They were philosophical conversations. I was immediately convinced by the idea of Philosophical Practice, because what should philosophy be about if not primarily about people's questions, the answers to which can give orientation to human life? Since I was a scholarship holder in Germany at the time, I got in touch with Achenbach and learned a lot from him. Back in my home country of Norway, I opened Norway's first Philosophical Practice in 1989 in Tromsø in the north of the country, where I got a position at the university.

This text was translated from German by Patrick Neubauer. It builds on a lecture "Therapeutic Effects of Philosophical Practice/ Counselling" given on the 3rd International Transdisciplinary Symposium Bioethics and Aporia of Psyche, Zagreb, 21-23 November 2019.

The text further develops, in a different thematic context, some thoughts I presented in my lecture "Ethics as First Philosophy" which was given at the Third International Conference on Philosophical Practice in New York in July 1997, and later published in German in: Anders Lindseth, Zur Sache der Philosophischen Praxis. Philosophieren in Gesprächen mit ratsuchenden Menschen, Verlag Karl Alber, Freiburg - München ${ }^{2}$ 2014, pp. 67-79. 
In the beginning, I tried hard to emphasise that Philosophical Practice is not therapy. It was my concern to make it clear that I would not offer treatment for mental problems or for suffering, but rather conversations to clarify life issues. This has remained important to me. However, it was clear to me from the start that such conversations can have a therapeutic effect, and this effect is still of crucial importance to me.

In this paper, I would like to determine the philosophical nature of philo-sophical conversations. For me, it does not consist in the application of philosophical theories, but the philosophical nature shows itself and takes place in the joint endeavour to listen to what the guest or guests of the Practice have to say and to clarify and examine it reflexively. Theories are not given in a fixed way as is the case in a mere technical application, but the experience of the dialogue is allowed to continuously challenge theoretical perspectives constituting the preunderstanding of philosopher and guest. ${ }^{2}$ What is the guest's story, which shows itself inevitably, about? This is my question, which I primarily ask myself as a philosopher, because the expectation that the guests should be able to answer this question themselves would overwhelm them easily. Rather, they sense what it is all about, and I am also beginning to sense something in the conversation. We can then talk about this together. My aim is trying to understand what might be at stake in the guest's story rather than knowing what is going on in the guest's life that might cause problems.

This I would like to clarify with an example. Some years ago, I talked to a guest in my practice, a family therapist just before retirement, who told me that she wanted to be there for her old friends. These were old friends she had for a long time, but who were also old in the sense that they aged. They were no longer that flexible and not too far from death either. But she experienced that being close to her old friends required a considerable readjustment. When, coming from her hectic everyday life, she took too little time for readjusting herself, her attitude towards her friends got somewhat tough, and neither she nor her friends were happy. I found the conversation very exciting, as did my guest. In an e-mail a week later, she told me that it still affects her, although it had just been a short conversation. It took place in the Institute for Family Therapy, where the woman worked, in the presence of her colleagues. They wanted to listen to me not only during my lecturing but also to learn concretely how I, as a Philosophical Practitioner, proceed in conversations. I was willing to do that if someone had something on their mind that they wanted to talk about to me; I would not have participated in mere role-playing. The therapist, who was about to retire, answered immediately. The feedback of her colleagues on our conversation was not surprising for me, but somehow it was in its clarity: they were surprised. They expected me to do almost the same as they did in their systemically oriented therapy sessions, and they found that I did something else. ${ }^{3}$ They were surprised that I immediately asked what the woman's story was about. What is the subject matter at stake in this story? That was my question. They themselves would have wondered first how they could help the woman, and to help they would need information about her factual life situation. My reaction to this was that I, as a philosopher, would not have to worry about helping, because a reasonably successful clarification of the essence of the story would be helpful enough. What is the necessary readjustment about? What does it mean that the woman's behaviour becomes tough if the readjustment is not successful? The therapists would see a problem here that they should help to solve. I instead see human behaviour and 
action that would have to be illuminated in the light of philosophical considerations. In doing so, I do not apply philosophy to the woman; I instead allow the story of the woman to challenge my philosophical understanding.

In the following, I would like to try to clarify further the difference between a philosophical dialogue and other dialogues, and I stay with the experience of my Philosophical Practice.

\section{Not an Easy Truth}

When couples come to Philosophical Practice, conflicts are often involved. One type of conflict (among many) is that the woman feels ignored by the man, rejected, pushed aside, not taken seriously, etc., while the man thinks that the woman's perspective is far too emotional and subjective because he only tries to stand up for what he believes to be true and right.

When we encounter such conflicts, we can ask: who is right? Is it true what the woman says or what the man says? Or are they both wrong? Or, even more complicated: are they possibly both right and wrong? Obviously, there is no simple truth here. Based on this finding, one may conclude that there is no truth at all in such cases. According to some therapists, there is not one given reality, but rather different descriptions and representations of it, and accordingly, their therapies are based on the motto "let's try a different description and see if we like it better".

I will not go against this view. However, I think that we as philosophers cannot say goodbye to the truth. Philosophising is, after all, a matter of truth. Otherwise, it would slip into non-commitment, or it would degenerate into the expression of the mere exercise of power. That what philosophising is about

2

This may be called hermeneutical (as opposite to technical or instrumental) application, which is considered "to be just as integral a part of the hermeneutical process as are understanding and interpretation". - HansGeorg Gadamer, Truth and Method, translated by Joel Weinsheimer, Donald G. Marshall, Continuum Publishing Group, London - New York 1989, p. 307. In a dialogue, ways of understanding are tried out, and thereby the philosopher is aware of bringing his or her preunderstanding into play. We might say that preunderstanding and not a given theory is applied. But this is an application through which preunderstanding appears, becomes conscious to some extent and thereby at the same time is challenged. An example of technical application might be therapeutic mirroring. A psychotherapist may use technics of mirroring to make clients more aware of what they are saying and expressing. Such mirroring (e.g. through repeating some words the client just has used or imitating gestures or the tone of speech) is based on theory (as e.g. the theory of mirror neurons) and it aims at achieving an effect. In Philosophical Practice you may of course say that there is an element of mirroring in the dialogical movement of receiving an impression from the guest's expression and then expressing this impression as a response to the original expression, but this is not a technic aiming at an effect. It is, rather, seen as the reflecting process in which reality is revealed. In my examples below I may respond by saying: "Oh, you become too tough... ? Well, it may be hard to allow yourself to be moved, just coming from everyday activity." "Ah, you feel your husband rejects you. How do you think your husband experiences your reaction?" "Alas, humans are vulnerable." And so on and so forth. There are endless ways of responding - and every practitioner must be free to develop his or her personal style.

About similarities and differences between systemic psychotherapy and Philosophical Practice, cf. Anders Lindseth, "Dialog und Dialektik - Wie Krisenerfahrungen durch offene Gespräche zu Neuorientierung im Leben führen können", Zeitschrift für systemische Therapie und Beratung 36 (2018), pp. 151157. 
for us, since it is neither mere chitchat nor the mere assertion of one's interest, is what we appropriately call "truth".

But this truth is not simple. By "simple truth" I mean, for example, the appropriate description or explanation of a given fact. That a description or explanation is adequate would mean that we could see good reasons that would make us agree with the description or explanation. A statement would therefore be true (in a simple sense) if and only if it stated the factual nature of given facts. But the truth that is at stake in a marriage dispute is not such a simple truth, because it is not about given and existing facts, but about the historical reality of both the woman and the man, and of the two as a couple. We are dealing here with a historical reality that is composed of several stories.

Thus, we are encouraged to ask not so much about what is the case in these stories but rather what is at stake in them. For stories have a beginning, a course and an end. The beginning can be good or bad, the course can be happy or unhappy - and the end can satisfy us or not. We live in history, and in this historical life, life itself is at stake. By this, I do not mean that we can die, which we will do anyway, but that life can be successful or not. Perhaps there is no such thing as a pure and complete success in life, but there are many kinds of failures, and accordingly, there are also many kinds of success. What is at stake in human life? What is important in this life?

It is not possible to take a quick and easy stand on the historically lived reality. If we ask ourselves, for example, whether the woman in a conflict of the type mentioned has really been rejected, pushed aside or the like, we are probably too quick to judge. We must first ask what it means that she has been ignored, rejected, not taken seriously. Then we have to let the woman's story speak to us. We must allow her story to make an impression on us and also assume that she has something important to tell us. The same goes for the story of the man.

Thus we are not in a position to look into a given situation and take a stand on what is going on, but we encounter a voice, a story, a self-expressing life, and we must be ready to hear the message of that voice, the expression of that life. Our problem with this is that we usually tend to know too quickly what it is all about.

\section{Ethics as First Philosophy}

I want to support a thought Emmanuel Lévinas so strongly advocates: that ethics must be first philosophy.

Lévinas rejected a figure of thought he considered a characteristic of Western philosophy and science. According to this figure of thought, recognition means subjugating the unfamiliar. It is being done by fitting the object of recognition to familiar categories, adapting it to familiar concepts and explaining it according to established theories or models. It is considered important to decide what $i s$, by way of developing a doctrine of being (an ontology), or - in modernity - to make sure that recognition works according to plan in describing being (developing an epistemology). Only then, after acquiring reliable knowledge about reality, does it become possible to establish what is right and wrong and to develop ethics. Lévinas rejected this approach of subordinating the object to the subject, which leads us to think that we should take control over reality. He particularly rejected this philosophy because it excludes us from individuality. We do not permit it to enter into our world unless it fits our established concepts and categories. With that, we shut 
experience out. ${ }^{4}$ We maintain our image of the world, our theoretical knowledge $^{5}$ - which we may modify and add nuances to - but never let go of our attachment to the familiar so that the individual Other is permitted to enter into our world of experience.

This becomes particularly crucial when we meet the individual other person. Lévinas builds his whole philosophy on the fundamental experience that the other person constitutes a reality the subject cannot conquer, but which it is always already subjected to (Latin: sub-jectum - thrown under). The Other invades my world as vulnerability and silent appeal, as something invoking my responsibility even before I begin to understand. Understanding the Other is particularly subjected to the appeal for responsibility. Ergo I enter an ethical field before I understand. Ethics - not ontology or epistemology - must, therefore, according to Lévinas, be "first philosophy". ${ }^{6}$

Lévinas points to an original dimension of experience covertly disguised by knowledge. He emphasises one basic experience: the experience of the Other - and particularly the other person. The Other, phenomenologically understood, is all that exceeds my categories, that does not completely fit my concepts, preconceptions and theories. The other human being is the unique person who meets me, whose face is not identical to any other face, and who deserves my reverence in his or her vulnerable and almost obliterate individuality. That which easily extinguishes the individual, unique and Other - is my knowledge. It happens by way of my experience of the Other becoming suspended by my knowledge: the moment I think I have knowledge I no longer need to sense the message from experience since I already know

It is an old idea that we have to learn from experience. Sensing and perceiving the world is the basis for understanding it; what our intellect can tell us is already implicitly contained in our sensory impressions. But understanding and conceptual knowledge may hinder us from learning the lesson of experience. Thinking that we know may reduce our ability to be moved by lived experience. German philosopher Wilhelm Dilthey differentiated between Erleben and Erfahren, a differentiation which works well in German but requires an extra term in English: Erfahren is experience, and Erleben becomes - lived - experience. That is an experience which we simply have in life without concluding anything from it. Lived experience is more felt than known. Only when we express it, through word or deed, we realise what it is about. Then we learn a lesson. Dilthey emphasised that although the whole life context is already given in our lived experience, we can only experience and recognise it when we explain it conceptually and narratively. Lived experience is the inside of experience, so to speak, without which the conscious experience would make no sense - and would thus be impossible. Experience is the expressive movement from lived experience to understanding that may teach us a painful lesson without which we would be less able to deal with life.
Knowledge may be theoretical or practical. Theoretical knowledge I understand as propositions, assumptions, hypotheses, theories, models, explanations we regard as being true or at least probable, while practical knowledge shows itself in action, it is to a great extent of tacit nature and not always good and useful. That's why practical knowledge, just like understanding, has to be critically assessed. It is a result of such assessment that our belief in theoretical knowledge prevents us from accessing experience. - On practical knowledge, cf. Anders Lindseth, "Svarevne og kritisk refleksjon - Hvordan utvikle praktisk kunnskap?", in: James McGuirk, Jan Selmer Methi (eds.), Praktisk kunnskap som profesjonsforskning. Antologi over yrkeserfaringen som utgangspunkt for forståelse av kunnskapsutvikling $i$ praksis, Fagbokforlaget, Bergen 2014, pp. 43-60.

6

Cf. Adrian T. Peperzak (ed.), Ethics as First Philosophy. The Significance of Emmanuel Levinas for Philosophy, Literature and Religion, Routledge, New York - London 1995. 
what the facts are. Thereby experience becomes almost invalid. It needs to be in accordance with knowledge, and when it is not, the experience is wrong. Knowledge appears superior in its objectivity in relation to experience, which is seemingly subjective and coincidental.

\section{Freeing Ourselves from a Dominant Realist Tendency}

What is it which really prevents us from accessing experience? What prevents us from sensing what experience wants to tell us? I do not think it is our knowledge per se, but rather our attitude towards knowledge, our faith in it and our expectations to it. This attitude and faith become expressed as a strong and spontaneous tendency: a tendency to ignore experience and focus on knowledge; a tendency to expecting knowledge, and not experience, to provide the access we need to the world: the necessary and sufficient access to the truth of reality. Our attitude towards knowledge manifests itself as a dominating tendency to presuppose that we can exactly know what is the case.

This tendency is deeply rooted in us. It not only responds to strong needs in every one of us; it constitutes a dominant realist tendency in Western philosophy and science. It is presupposed that we should be able to know precisely how the world (or reality) is. We can know the facts. We can find out. At least as a matter of principle, we can find out, but we may lack criteria to decisively say whether we know. Realist positions can be naive or critical in their perception of how easy it is to recognise reality. They can also constitute widely different perspectives on the nature of reality. Antiquity's and Medieval realists meant to have found a moral as well as mathematical order in the universe - while realists in modernity eagerly have uncovered structural, causal and functional regularities in nature and society. Still, the realist tendency essentially remains the same: a tendency to orientate "outwards", towards objective order, facts, realities, what would presumably be the case irrespectively of our experiences or "inner" lives. This tendency to orientate towards the objective is normative in character: we should find out what the facts are. Our experiences, the narrative, the aesthetical and ethical become secondary.

If we seek to experience the Other, it demands that we disengage from the ruling realist tendency within Western philosophy and science. The thesis on the primacy of ethics implies dismissing this tendency. But what does dismissing mean in this context? What does it mean to disengage from a tendency to wanting to know?

It seems reasonable to think that dismissing an assumption means rejecting the assumption. Formerly we presumed A; now we embrace non-A. But what is it we reject if we dismiss the dominant realist tendency in Western philosophy and science? Dismissing such a tendency is not quite the same as dismissing a philosophical thesis or position. Dismissing a thesis or position can naturally be presented as a counter-thesis or opposing position. Dismissing a tendency, e.g. the tendency to want to know, is more of a change in attitude; one does no longer primarily want to know what is the case. Or the dismissal can be described as a change of values; in life's multiple situations knowledge no longer holds the most important position (at least not theoretical, propositional knowledge).

When I claim that the thesis on the primacy of ethics requires a dismissal of the dominant realist tendency in Western philosophy and science, what I have in mind is a change of attitude and values. I do not want to say that we need a 
counter-position to a dominant realist position. The debate between realist positions, on the one hand, and anti- or non-realist positions, on the other, I shall take no part in. It constitutes an academic-philosophical discourse, which I do not reject, but need to distance myself from to enable myself to say something about philosophy's purpose - and about Philosophical Practice.

I try to dissociate from the prevailing philosophical discourse with statement versus statement, thesis versus thesis, position versus position, and try to gain a foothold in an experience which reasoning can - and must - refer to so that it can prevail. I would like to leave a discussion which takes place "in mid air", in Kierkegaard's words, ${ }^{7}$ and establish contact with a lived and experienced reality that concepts, assumptions and statements must remain responsible to.

In this paper, I try to give experience precedence over knowledge. I try to escape from a theoretical discourse where experience is disguised by knowledge and intelligent statements. In other words: I try to break away from the dominant realist tendency I have been talking about. How can I do this within the framework of a paper? I can explain what it means to break away from an attitude which presupposes that we can know the exact facts. And I can recommend breaking away and argue that it is necessary. But thereby I make statements about something which I think is the case. I explain why it is important to take one's point of departure in lived experience. But does that enable me to bring the experience into the game? That is the almost unsolvable problem which the paper's theoretical discourse challenges me with. I do not only want to explain, but also to demonstrate what it means to dismiss the tendency to want to know, - in which case I would have to take my audience in on a journey into the dimension of experience, to a much greater extent than a paper allows me to do. I would have to let you in on a reflected journey into the landscape of experience, like I do in my Philosophical Practice. But this is impossible, for the simple reason that I neither can nor will permit you to decide where the road takes us, as I would in my practice.

My solution to this problem - and this will be no surprise to you - is to allow you to join me in the best way I can on a road I have decided myself. Let us go back to the initial situation I described earlier to see how it could form an experiential basis for reflected understanding.

\section{Re-Staging of Narratives}

The point of departure for our reflection - which I find to be a fundamental ascertainment - is a narrative. It will always be so in a Philosophical Practice: The guest at my practice tells me something. This is where it starts. The philosopher is faced with a narrative and must relate to it. But is that not quite obvious? Is it not characteristic of any dialogue that we relate to what the other tells us? Obviously, but the obvious is not what the philosopher deals with; he or she does not relate to what the narrative is about, but to the narrative itself. The narrative is the point of departure and not the reality the narrative is about. Here philosophy breaks away from the ordinary, everyday and natural

“... al denne Striden er dog paa afstand og som i Luften." - Søren Kierkegaard, Kjerlighedens Gjerninger, in: Søren Kierkegaard, Samlede varker bind 1-20, vol. 12, Gyldendal, Copenhagen 1962, p. 81. 
attitude. It is natural for an interlocutor to engage in the narrative and relate to its content, based on interest, curiosity and in a way which makes the narrator sense support or perhaps provocation. The average interlocutor becomes an agent in a re-staging of the narrative. That is exactly what the philosopher avoids. I will clarify what I mean.

Let us imagine that the married couple I have mentioned meets a friend and recounts the story of the conflict. If the friend is a man, he might perhaps say to the woman: "My dear, it is not really much to worry about, is it?" And perhaps he would say to himself: "Women! Always the same fuzz!" If the friend is a woman, she might say to the man: "You men are all the same, you seem to think you know how to define what's important in any situation." This demonstrates clearly that the friend, female as well as male, relate to the reality the narrative deals with, and not to the narrative itself. And the person in question not only relates to the reality, but assumes a position in relation to it, and tries to influence it. Here he or she becomes an agent in a narrative which takes place as an extension of the original narrative where the married couple played the only roles.

We can try another thought experiment. Let us imagine the married couple telling their story to a psychotherapist. He or she will not do as their friends nor like the philosopher. The psychotherapist avoids interfering with the narrative as the friends do. It would be irresponsible and unprofessional. But, on the other hand, psychotherapists (and then I mean the ideal-type psychotherapists, not any psychotherapists) would not relate to the narratives dimension as the decisive basis of experience. They would regard the narrative as information about a life-situation their clients see as problematic. Psychotherapists will try to form a picture of this life-situation to discover which problems they can contribute to solving. By doing so, the psychotherapists also relate to the life-situation the narrative concerns, but in a "professional" way, as opposed to the friends who are led by their interests. The friends immediately recognise the situation, whereas the psychotherapist spends some time assessing it.

The philosopher breaks away from the narrative's interest for and involvement in the situation. The philosopher removes himself or herself from the narratives perspective of the situation and focuses on the narrative itself not only with his or her gaze but also with his or her hearing, all the senses, all sensations. This breaking away from a natural direction of gaze does not mean that the philosopher would rather not know anything about the factual situation. It may be an advantage to know something about it, and for a number of reasons, the philosopher might want to gather information about it. The philosopher's point of changing the direction of his or her gaze, is not to become "unprejudiced" towards the situation, but to refrain from voicing an opinion about it, to refrain from already knowing what it is like. The philosopher refrains from meeting the person who is a guest of his or her practice on the same basis as the friends or the therapist: on the basis of knowledge.

The friends and the therapist mean to have a basis for making a judgement: this is the real case; this is what the situation really is! This judgement - it is important to emphasise - is not only descriptive. It is also normative ("It is wrong to feel rejected by one's husband on this basis." - "The man should not repress his wife the way he does."). Remaining with the narratives' view on the situation means to evaluate the situation - to know that this is how it is and this is how it is not, that this is how it should be and this is how it should not be. The friends, as well as the therapist, believe they can have an unques- 
tionable basis for relating to the situation, a basis of knowledge. This does not imply that they think they know all about the situation. They may well be in doubt and want to gather information about a number of things, and to learn more about one aspect or the other. But the moment they go into the narratives' involvement in the situation, they feel confident that they know something significant, something essential - something so important and essential that they can interfere with the narrative, have an opinion about the situation, influence it and exert their power.

For the friends, as well as the therapist, it seems obvious that knowledge is a reliable fundament to act upon - as long as it is well-founded. In this obviousness, our great expectations to knowledge become evident. We believe we can know exactly what the case is, and what is relevant, so that we can relate to and interfere with any situation. We do not necessarily have a reflected relationship to this faith in knowledge - usually, we do not - but we act upon it. We have a tendency - in life's different situations - to act with knowledge's pretensions, ambitions and authority. In everyday life, in science, in all kinds of expert practice, this tendency appears. It is deeply rooted in us. It is this which I have called "the dominant realist tendency in Western philosophy and science".

It is a wide-spread tendency for many good reasons. The tasks of everyday life cannot be mastered and solved without knowledge. Knowledge is an essential basis for all social life, probably a precondition for our survival as species. Besides, our culture has since early Greek philosophy carried an enormous fascination with knowledge, in particular exact structural knowledge, the knowledge we can have about the heavens. At the beginning of modernity Galileo demonstrated that we can have the same exact, mathematical knowledge about nature here on earth. How strongly this knowledge has shaped our civilisation becomes apparent in a time coloured by increasing digitalisation of all communicative media. It seems as if reality itself is composed of information. The tendency to act knowingly has entered into our blood-stream, or maybe our blood has already been substituted with a stream of digitally encrypted information.

\section{To Disengage from the Narrative's Involvement in Factuality}

The philosopher disengages himself or herself from the narrative's involvement with the situation and focuses his or her attention and interest in the narrative itself. In doing so, the philosopher dismisses the tendency to behave knowingly. The Philosophical Practitioner does not meet his or her guest with the question in mind: is it true what I'm being told? But instead with the question: what is the meaning of that which is said and expressed? What does this narrative imply? The shift of gaze from situation to narrative is a transition from the factual to a dimension of meaning and significance. However, as already stated, this does not mean that the philosopher leaves all reference behind to enter into a separate ideal world of meaning. With senses and sensation, the philosopher remains present with the situations and the life which the guest tells them. When the philosopher refrains from behaving knowingly he or she does not do so in order to distance himself or herself from the situation, on the contrary, he or she does so in order to go more consciously into it and closer to it, together with the guest, but based on lived experience, not theoretical knowledge. 
When, for example, a woman tells her story of suffering from being ignored and rejected, the philosopher is not interested in judging her story based on any criteria whatsoever according to whether she has really been rejected, pushed aside and not taken seriously or not. Rather, the philosopher is concerned with sensing and - in his or her own way - understanding what experience it expresses. The expression must make an impression on the philosopher so that he or she can go with the lady's experience. All kinds of rash statements are out of place here. The woman experiences that she does not come into play, that her husband somehow disqualifies her, and first of all, it must be a matter of clarifying what she is experiencing, how she is experiencing it, and under what circumstances she is doing that.

I would now like to emphasise very strongly that I do not mean a subjective state of the woman when I speak of her experience. The subjective or mental states belong to the factuality for which the psychologist is responsible. No, the woman lives and experiences her life, and so she learns what it is about. She does not have to understand or like what she is experiencing, but she will always be able to try not only to take into account what she has experienced but also to put it into words. Putting it into words is, if not necessary, then in any case very helpful for the completion of the experience. ${ }^{8}$ Only by telling it can she become aware of the inconsistencies of her narrative and the problematic nature of her experience. What she puts into words does not have to suit her husband, and the way she does it does not have to be balanced or smart.

The fact that the Practitioner wants to participate in her experience through her narrative does not mean that he generally agrees with this narrative and its expression. Rather, he is wondering about what he hears, and from this wondering, his questions and assumptions grow. Together with the woman and her husband, he might think about to what extent the discourse of the woman could be judged by standards, and also which standards could be considered. Such a consideration is obvious in this case because the husband is applying standards: he finds her reaction too emotional and not objective enough. Perhaps his distance from the topic of rejection affects him in a much more difficult way than his wife. Here, many questions arise that must be asked to clarify and understand the man's experience, which could well be more hidden than his wife's experience. It then also has to be considered what is wisdom or stupidity in the discourse of the man. This is all very exciting, and it does not really lead away from reality. It may be so exciting that the Philosophical Practitioner has to be very careful in the proceeding and clarifying. The condition for such clarification is the exclusion of any rash statement about what is real and factual, because such a statement is usually guided by the interest in achieving advantages and avoiding inconvenience.

What distinguishes the Philosophical Practitioner from the friend or from the therapist can, in the language of phenomenology, also be expressed in such a way that the Philosophical Practitioner moves from the natural to the phenomenological attitude, so that he pays more attention to the life-world than to factuality.

"To shift to the phenomenological attitude we must refrain from making judgements about the factual. We must accomplish epoché or bracketing. The easiest and, so to speak, the natural way of doing this is to narrate from lived experience. Thus narrating, we naturally refrain from judging and concluding. We are not interested in stating facts, but in relating what we have experienced. Then the listener may also not judge: 'What you say is right or wrong', but rather participate in the story: 'So this you have experienced, so that is what you thought'. In the telling, both 
the teller and the listener take part in the narrated meaning. Then they are free to consider: what are the important themes here, the essential characteristics of the expressed meaning?"

Philosophical dialogue is a movement from the narrative, not to the factual situation the narrative is referring to, but toward the narrative's issues. What is at stake in the narrative, what is it about? ${ }^{10}$

\section{To Meet the Expression of the Guest as Self-Communication, Neither as Informing nor as Addressing Someone}

Due to the philosopher's attitude, the conversations in the Philosophical Practice differ from the usual everyday conversations. We know from our own experience what this attitude is about. We have all had the experience that we met or even visited a human being whom we wanted to tell something, but then it became clear that he or she was not open for what we had to say. Then we do not want to open up anymore. If it is nothing personal we wanted to talk about, it will usually be rather easy to accept the other's lack of receptivity, but if we have something really important to say, we might feel it as insulting when we are not listened to. Maybe the other has given the impression to listen to us so that we have started to express ourselves, but then we realise that we do not really reach him or her with what we have to say. Then we feel hurt; we feel rejected.

We have also all had the opposite experience: we are listened to, with openness and attention for what we try to express. We encounter a human being who is interested in listening to what we have to say, and therefore it is easy for us to speak. We are invited into a space of attention in which our expression finds its voice. There, we find words for what we want to say, often striking or even surprising words. We find an open ear, and thus we can listen to ourselves. That can mean that only then we realise what we are saying, that we realise what we are truly troubled with. Life which finds an expression in what has been said gains a new option to re-shape itself in the dialogue. Perhaps we say something we have already said before, maybe even many times. Then, we know what we say. However, we might know it all too good. We are actually finished before we even said it.

However, when words meet an attentive listener, something happens. They gain new relevance. We listen to them in a new way. We are somewhat infected by the listener's attention, who listens to what has been said as something

8

Such reflection Paul Ricœur calls "concrete reflection". Cf. Paul Ricœur, The Conflict of Interpretations. Essays in Hermeneutics, Northwestern University Press, Evanston 1974, p. 265.

Anders Lindseth, Astrid Norberg, "A phenomenological hermeneutical method for researching lived experience", Scandinavian Journal of Caring Sciences 18 (2004) 2, pp. 145-153, p. 147.

10

Anders Lindseth, "What The Other Says - And What (S)He Talks About. Some
Foundations of a Theory of Philosophical Practice", in: Trevor Curnow (ed.), Thinking Through Dialogue. Essays on Philosophy in Practice, Practical Philosophy Press, Surrey 2001, pp. 134-136. Here I emphasise that my colleague at the University of Tromsø, the social psychiatrist and family therapist Tom Andersen (who died 2007) in his work lets himself be guided by a hermeneutic principle, the principle to let oneself be guided by touched not-knowing, or shorter: the principle of touched not knowing. 
new. Suddenly, what has been said appears with the quality of something new. This might explain what often happens in such a dialogue; both partners afterwards have a better mood than before. And this is not only because something important was touched upon in the dialogue but rather because one has entered a movement in which life forces have been set free. One feels livened up. This is quite the opposite of a process where you try to put what has been said into a frame of systematic theoretical knowledge, such as medicine, sociology or psychology.

Experiencing a space of attention, which can open up or close down when encountering a receptive or an unreceptive dialogue partner, is a fundamental human experience. In this encounter, which takes place in the space of the dialogue, life gets its shape. The encounter means help or obstacle for orientation on our way of life. We try to express ourselves, we dare to enter such an expression and we experience how exposed we are to the acceptance of the other, especially those who are close to us. In this process, important conditions are shaped, which make our life a happy or an unhappy one. Thus, it is an ethical demand for every one of us to accept the life expression of those who dare to express themselves. K. E. Løgstrup puts it the following way:

"Regardless of how varied the communication between persons may be, it always involves the risk of one person daring to lay him or herself open to the other in the hope of a response. This is the essence of communication and it is the fundamental phenomenon of ethical life. Therefore, a consciousness of the resultant demand is not dependent upon a revelation, in the theological sense of the word, nor is the demand based on a more or less conscious agreement between the persons with respect to what would be mutually beneficial." 11

The ethical demand the philosopher has to face is due to the vulnerable expressing-oneself of the guest. ${ }^{12}$

When life is at stake in a fundamental sense, each of us is confronted with the urgent question of how to take in the expression of the other. In many dialogues in different life contexts, it does not become obvious that so much is at stake. However, in different contexts, in which we realise in the encounter that we are holding a part of the other's life in our own hands, we cannot escape from the ethical demand which is given by the encounter itself. How can we open up the space of attention in which the other is listened to and can listen to him- or herself? This is a crucial question for Philosophical Practitioners. In other relations, it might be better to do something practical. However, it is difficult to take in an expression of life that dares itself towards an encounter without allowing oneself to be touched and moved by this expression. And it is this readiness to be touched which opens up the space of attention and allows the movement of life to develop new energies.

The Philosophical Practitioner opens up the space of attention by refraining from knowing in advance what the expression of his guest is or could be about.

But what are we actually doing when we refrain from knowing things in advance? The ancient sceptics recommended refraining from knowing things with certainty. If we try to find out exactly what life is about, we do not find peace of mind. To let go of such certainty and exactness, that is epoché. Edmund Husserl took over this term and used it to name a decisive element or a step in his phenomenological method: if we want to find out the fundamental meaning of phenomena, we first have to put into brackets the given opinions about the phenomenon. We have to refrain from already knowing. ${ }^{13}$ 
We refrain from knowing at once that guests are talking about a problem they would like to see solved. We also refrain from knowing in advance that they are talking about their desires or about their illness or about something else fitting into the field of knowledge we are experts in. Refraining from that does not mean giving up all knowledge. We should rather talk about a change of attitude. Instead of confronting the guests with the knowledge we already have, we rather take in what they express. We are prepared to let the expression of the guest leave an impression on us, being unprotected, without seeking refuge in a field of knowledge in which we feel safe. We do not reject fields of knowledge, rather, we do without their protection in our direct encounter with the guests. This is something they feel. If we encounter a guest with openness and receptivity, the space of attention opens up, in which the guest's expression can find its voice and in which the guest finds orientation within his narration. If we instead confront the guest with our readiness to classify what has been said into categories, explanations and models, this space is closed or remains closed. Then expression is reduced to information, which can or cannot be useful for the counsellor or helper. It then has become clear that the guest who is looking for advice and help is less competent to understand what has been said than the helper or counsellor. In Philosophical Practice, the expression would then no longer be an expression of the guest's life which he or she can identify with. Instead, the guest would be reduced to a carrier of information or even declared incapable of managing own life affairs. A dialogue community, in which the guest and the philosopher can meet to discuss their experiences - especially those of the guest - is subjected to a system demanding correctness, and then it collapses. A system has already colonialized the life-world. ${ }^{14}$ Thus, we manage the first step of our method - refraining from knowing in advance - by allowing the guest's expression to leave an impression on us. This impression has an effect on the expression - not as a result of an active, controlling impulse but rather in the form of an invitation (such an effect is structive, not causal. ${ }^{15}$

As Philosophical Practitioners, we refrain from being experts who can know better than the guests what their problems are. We may know many things from experience and from studies, but we refrain from meeting the guest from the position of a knower. We do not give up knowledge, but we have integrated it into ourselves to such an extent that we can dare to meet the guest's expression in such a way that we get an impression of the expression

11

Knud Ejler Løgstrup, The Ethical Demand, University of Notre Dame Press, Notre Dame - London 1997, pp. 17-18.

12

The ethics of Løgstrup is very much on line with the ethics of Lévinas, although they did not know about each other.

13

Edmund Husserl, Ideen zu einer reinen Phänomenologie und phänomenologischen Philosophie, Erstes Buch, Martinus Nijhoff, Haag 1950, $\$ 32$.

14

Cf. Jürgen Habermas, Theorie des kommunikativen Handelns, vol. 2, VI. Zweite
Zwischenbetrachtung: System und Lebenswelt, Suhrkamp, Frankfurt am Main 1981, pp. 171-293.

15

Cf. Reinhard Falter, "Sinn-Bilder. Warum es sinnvoll ist, Natur-Charaktere mit Götternamen zu benennen", Hagia Chora 20 (2005), pp. 94-97; Anders Lindseth, "Wirken Philosophischer Praxis", in: Thomas Gutknecht, Beatrix Himmelmann, Thomas Polednitschek (eds.), Philosophische Praxis und Psychotherapie. Gegenseitige und gemeinsame Herausforderungen, Lit Verlag, Berlin 2008, pp. 10-24. 
without any protection. In this way, we acknowledge the guest's expression as self-communication, and this is precisely what gives the guest the freedom to perceive himself anew.

However, the recognition of the guest's expression as self-communication is not only endangered by an expert knowledge that reduces expression to information. In ordinary conversations of everyday life, we usually take the other person's expression as a form of address that challenges us to react immediately. We engage in a narrative and contribute to re-staging of narratives, just as the friends of the married couple. Thus we are already entangled in what Foucault calls "discourse". ${ }^{16}$ We find ourselves in forced situations in which we have to agree or to defend ourselves. We do not perceive the expression of the other as self-communication but rather as a possible, implicit or explicit accusation, and the usual strategy to ease such accusations, which we often need, is to take refuge in pleasure, in entertainment and in not being committal.

Philosophical conversations not only free us from the constraints of expert knowledge, but also from the constraints of discourse. This frees us to understand the other's expression as self-communication, in a similar way as we can experience nature, as an expression that does not demand anything else from us than participating in nature's self-communication. Such communication sets us free to sense what is moving in us and in our lives.

As Philosophical Practitioners, we are challenged to locate the guest's self-communication in nature and in freedom. Sure, the guest's self-communication is not independent of the interests of discourse, but in the dialogue of Philosophical Practice, these interests are not acted upon as social discourse, but reflected as discourse of the other person, as self-communication. That is a small difference with huge consequences: the guest, as well as the practitioner, may find new orientation in life. ${ }^{17}$

\title{
Anders Lindseth
}

\section{Što je na djelu u pripovijesti gosta filozofijske prakse?}

\begin{abstract}
Sažetak
U dijalogu filozofijske prakse, filozof se neprekidno mora pitati o tome što je na djelu u pripovijestima gosta. O čemu su zapravo njihove priče? Posebna je, respondibilna pozornost potrebna u takvim dijalozima. Ovaj je rad pokušaj da se razjasni razlika između filozofijskog dijaloga $i$ drugih dijaloga, kao što su svakodnevni dijalog i dijalozi s ekspertima, naročito profesionalnom pomoći. Filozofijska praksa razumije se kao posvećena tumačenju gostove poruke kao samokomunikacije, dok se izvan prostora prakse uobičajeno iskušava kao oblik obraćanja ili informacije. Etični je to izazov da filozofijski praktičar može otvoriti prostor pozornosti u dijalogu u kojem se samokomunikacija gosta može sagledati iznova i omogućiti novu orijentaciju u životu. Filozofijska praksa smjera $k$ oslobađanju takve samokomunikacije od diskursa $i$ k njenom lociranju u prirodi i slobodi.
\end{abstract}

\section{Ključne riječi}

dijalog, diskurs, etika, hermeneutika, informacija, narativ, fenomenologija, realizam, samokomunikacija, istina 


\title{
Anders Lindseth
}

\section{Was ist in der Erzählung des Gastes der philosophischen Praxis am Werk?}

\begin{abstract}
Zusammenfassung
Im Dialog der philosophischen Praxis muss sich der Philosoph ununterbrochen fragen, was in den Erzählungen des Gastes am Werk ist. Wovon handeln die Geschichten wirklich? Eine spezielle, responsive Aufmerksamkeit ist in solchen Dialogen geboten. Die vorliegende Arbeit ist ein Versuch, den Unterschied zwischen dem philosophischen Dialog und anderen Dialogen, wie dem täglichen Dialog und den Dialogen mit Experten, insbesondere mit professionellen Helfern, zu erhellen. In der philosophischen Praxis geht es darum, die Botschaft des Gastes als Selbstmitteilung zu verstehen, während sie außerhalb des Praxisraums gewöhnlich als Ansprache oder als Information erfahren wird. Es ist eine ethische Herausforderung, dass ein philosophischer Praktiker einen Aufmerksamkeitsraum innerhalb eines Dialogs eröffnen kann, in dem die Selbstmitteilung des Gastes neu gesehen, und somit eine neue Orientierung im Leben zuwege gebracht werden kann. Die philosophische Praxis steuert auf das Ziel hin, eine solche Selbstmitteilung vom Diskurs zu befreien und sie in Natur und Freiheit zu verorten.
\end{abstract}

\section{Schlüsselwörter}

Dialog, Diskurs, Ethik, Hermeneutik, Information, Narrativ, Phänomenologie, Realismus, Selbstkommunikation, Wahrheit

\section{Anders Lindseth}

Qu'est-ce qui est à l'œuvre dans le récit du convive de la pratique philosophique ?

\begin{abstract}
Résumé
Dans le dialogue de la pratique philosophique le philosophe doit sans cesse s'interroger sur ce qui est à l'œuvre dans les récits des convives. De quoi parlent leurs histoires au juste? Il est nécessaire d'accorder une attention particulière aux réponses dans de tels dialogues. Ce travail s'attache à mettre en lumière la différence entre le dialogue philosophique et les autres dialogues, comme les dialogues quotidiens et les dialogues entretenus avec des experts, en particulier ceux proposant une aide professionnelle. La pratique philosophique est comprise comme étant dévouée à l'interprétation du message du convive en tant qu'autocommunication, alors qu'à l'extérieur de l'espace de la pratique elle est de manière générale perçue comme une manière de s'adresser l'autre ou comme une forme d'information. C'est un défi éthique pour le philosophe praticien d'ouvrir l'espace d'attention dans un dialogue au sein duquel l'autocommunication du convive peut être considérée à nouveau et permettre une nouvelle orientation dans la vie. La pratique philosophique vise à libérer le discours de cette autocommunication et à la situer dans la nature et la liberté.
\end{abstract}

\section{Mots-clés}

dialogue, discours, éthique, herméneutique, information, narration, phénoménologie, réalisme, autocommunication, vérité

16

Cf. Michel Foucault, Die Ordnung des Diskurses, translated by Walter Seitter, Fischer Taschenbuch Verlag, Frankfurt am Main 1991 (L'ordre du discours, Gallimard, Paris 1972).

17

In systemic therapy the approaches of Reflecting Processes, developed by Tom Andersen and colleagues (cf. Tom Andersen, The Reflecting Team. Dialogues and Dialogues about the Dialogues, W. W. Horton, New York 1991), and Open Dialogue, developed by Jaakko Seikkula and colleagues (cf. Jaakko
Seikkula, Mary Olson, "The open dialogue approach to acute psychosis", Family Process 42 (2003), pp. 403-418), may also free us from the constraints of expert knowledge and everyday discourses. That is the philosophical distinctiveness of these therapeutical approaches, making us open for the essential of life narratives. Cf. Anders Lindseth, "Being Ill as an Inevitable Life Topic. Possibilities of Philosophical Practice in Health Care and Psychotherapy", in: Michael Noah Weiss (ed.), The Socratic Handbook, Lit Verlag, Wien 2015, pp. 45-66. 